Afric

ArXiv

Article title: SEX EDUCATION AS A FOUNDATION OF CHRISTIAN FAITH

TO THE HOLY DOCTRINES

Authors: davidming ming[1]

Affiliations: Soekarno Hatta 399[1]

Orcid ids: 0000-0001-9649-1622[1]

Contact e-mail: restorasisttinjili@gmail.com

License information: This work has been published open access under Creative Commons Attribution License http://creativecommons.org/licenses/by/4.0/, which permits unrestricted use, distribution, and reproduction in any medium, provided the original work is properly cited. Conditions, terms of use and publishing policy can be found at https://www.scienceopen.com/.

Preprint statement: This article is a preprint and has not been peer-reviewed, under consideration and submitted to AfricArXiv Preprints for open peer review.

DOI: $10.14293 / 111.000 / 000015 . v 1$

Preprint first posted online: 13 January 2021

Keywords: Sex education, sinfulness, holiness, reformed doctorate 


\title{
SEX EDUCATION AS A FOUNDATION OF CHRISTIAN FAITH TO THE HOLY DOCTRINES
}

\begin{abstract}
Today's world continues to change, including the way people perceive sex problems. Some of the problems that arise are: What is meant by education? Sex in a world of sin? How is the Relationship of Sex Education as a Foundation of Christian Faith to the Doctrine of Holiness according to Reformed? The answer: (1) The Bible's view of sex education is God's work on humans since creation. (2) Sex is something sacred as God instituted marriage for the first time in Eden. (3) Sex education can be related to the doctrine of holiness as the foundation of Christian faith as follows: First, it is necessary to develop holiness education in schools, seminars and in churches in order to clarify the position of sexual sinfulness committed outside of marriage. Second, God-centered holiness becomes dependent only on God and not on humans. Third, the holiness modeled by Jesus becomes a figure that everyone can imitate so that everyone has a calling to live. Keywords: Sex education, sinfulness, holiness, reformed doctorate
\end{abstract}

\section{INTRODUCTION}

In the history of Christianity, sexual problems were seen as a sin that could be forgiven if it produced offspring. Sexual function is seen as merely a means of producing offspring. This view makes a married couple feel guilty when having sex. Various views about sexual. There are certain tribes who consider sexuality taboo. In certain tribes, customs regulate the sexual behavior of adherents. ${ }^{1}$ The fact that the high rate of child sexual violence in Indonesia is a big scourge that needs special attention. Based on data from the Indonesian Child Protection Commission (KPAI), it shows: 218 cases of child sexual violence in 2015, 120 cases in 2016, 116 cases in 2017, 117 cases in 2018. Furthermore, the Indonesian Child Protection Institute East Nusa Tenggara argues that the population 5.03 million of these people have been categorized as an emergency of sexual violence against women and children, showing data that around 503 cases occurred from 2015 to $2018 .^{2}$

The word "sex" (English sex) means gender. There are several terms which have the same meaning, namely: sex, sexuality and sexuality. This definition is as follows: (1) Sex is a process of reproduction or differences in sex characteristics, and it can also be related to all matters relating to pleasure or pleasure of organs combined with stimulation of the genitals or related to sexual love and sexual intercourse. (2) Sexual is related to behavior, feelings or emotions combined with

\footnotetext{
${ }^{1}$ The Batak tribe views sex as taboo. Taboo means that what is prohibited is considered sacred and should not be touched, pronounced because it is taboo and prohibition. So the Batak people consider sex as taboo. It is awkward for a Batak to talk about sex with a sister even between a father and his daughter.

${ }^{2}$ Angelikus N. Koten, Kristin Margiani, Beatriks N. Bunga, \& Timoteus Mau, (2019), "Parents' Perpesi on Sex Education of Children Ages 4-5 Years in Manleten Village, Tasifeto Timur District, Belu Regency,", Journal of Humanizing Education, XVIII (2), 79.
} 
stimulation of the pubic organs, erogenous area, or combined with the reproductive process. (3) Sexuality is the capacity to have sex or to seek sexual relations or a character being attracted to a sexual point of view.. ${ }^{3}$

Sex is instinctive in humans. Sex is a basic human need. If humans are restrained and castrated with their sexual desires, there will be various negative impacts surrounding them as well as impacts on the surrounding environment, but sex cannot be acted freely as well. The pros and cons of attitudes about sex education. For example a survey on sex education in schools shows that the understanding of sex education that is owned by grade $\mathrm{X}$ SMK Dr. Soetomo Surabaya said that parents think sex education is unnecessary because they think it has been given at school and later they will know for themselves. ${ }^{4}$

People still think negatively about sex education. There are some parents who have negative perceptions about sex education for early childhood. Some findings regarding negative perceptions where some parents expressed the opposite of positive perceptions, namely parents do not know sex education for early childhood, parents do not understand sex education for early childhood and, parents are unable to apply sex education to their children. In addition, there are parents who think that giving sex education is only appropriate for a mother because the mother is the closest to the children, and there are also parents who still think that sex education is still taboo, they should not be given to children until such time. later when they are grown (already experienced sexual maturity). ${ }^{5}$

Syafrudi's research on sex education also concludes contra that sex education for children with special needs is now something that must be considered. In addition to being a basic need for every child with special needs, sex education in theory, philosophy and juridical has a strong foundation. However, along with the differences in the abilities and characteristics of each child with special needs with normal children in general, practically sex education must be provided through flexible materials and methods. ${ }^{6}$

\footnotetext{
${ }^{3}$ Nuryadi, (2016), "Reproductive Education (Sex) in Adolescents", Journal of Religion and Society Studies, 12 (1), 82.Nuryadi, (2016), "Pendidikan Reproduksi (Seks) Pada Remaja”, Jurnal Studi Agama dan Masyarakat, 12 (1), 82.

${ }^{4}$ Ria Rosela and Retno Lukitaningsih, (2014), "A Survey on the Understanding of Sex Education for Class X Students at SMK Dr. Soetomo Surabaya ", Journal of BK UNESA, 04 (03), 1-12.

${ }^{5}$ Angelikus N. Koten, Kristin Margiani, Beatriks N. Bunga, \& Timoteus Mau, (2019), "Parents' Perpesi on Sex Education for Children Ages 4-5 Years in Manleten Village, Tasifeto Timur District, Belu Regency," 92.

${ }^{6}$ Safrudin Aziz, (2014), "Sex Education for Children with Special Needs", Journal of Education, II (2), 203.
} 
This writing provides a solution about sex education by raising several questions: What is meant by education? Sex in a world of sin? How is the Relationship of Sex Education as a Foundation of Christian Faith to the Doctrine of Holiness according to Reformed?

\section{METHODOLOGY RESEARCH}

This paper uses a literature research method in the form of books and articles as well as various writings that discuss sex. Also through observation through developing views around sexual issues through customs adhered to by certain ethnic groups or information through print and electronic media. This research method will thoroughly explain the meaning and function of sex according to the biblical perspective as the foundation of Christian faith. This article will also address issues that arise around sexuality in marriage. Then the discussion will be divided into two parts. The first part will discuss sex according to the Bible's perspective, the second part will discuss sexual life in marriage.

\section{RESULT}

\section{Sex Education}

Sex has been a gift from God since creation. Allah created man in His image, male and female were created and equipped with their respective sexual devices Gen. 1:27). God saw His creations as perfect and good, and then He placed them in the garden of Eden (Gen. 1:31; 2:15). It is good for humans to enjoy God's creation, communicate with other creatures, eat and drink, and have marriages according to God's will (Gen. 1:28, 29).

Humans are sexual creatures, because God has given sexual organs to humans and God declares them to be good (Gen. 1:31). Sexuality includes biological factors, gender, feelings, traits, behavior and values. Humans as sexual beings must be authentic, meaning that they are real, genuine, trusted as part of the human body, then we can defend God's creation and declare it good.. ${ }^{7}$

Sex as a gift of God is worth enjoying. Wise advice from King Solomon states: "Enjoy life with the wife you love for the rest of your life, which God has given you under the sun, because that is your part in life and in the work you do with the hard work under the sun" (Pkh 9: 9).

\footnotetext{
7Jack O. Balswick \& Judith K. Balswick, The Family (Grand Rapids, Michigan: Baker Book, 1989), 209.
} 
Sex "becomes one flesh". The phrase 'become one flesh' means total unity in the spiritual and spiritual body between the two spouses. This total union can be achieved through sexual intercourse between husband and wife through certain phases ${ }^{8}$

God places almost the highest priority in the sexual union in marriage, we can see in the book of Genesis that God man follows evil habits (Gen 2:17), the next teaching teaches men and women how to have a relationship in marriage. a man will leave his father and mother and be united to his wife, so that the two of them will become one flesh "(Gen. 2:24). God had to separate the male and female when he created Eve. But now He commands them to become one flesh.

Before sin entered mankind, we find three basic commands: first, if a person marries, he must let go of his dependence on his parents. He becomes completely dependent on his partner to meet all his needs. Second, the man is the one who is responsible for joining the marriage by "being" with his wife. Unite means that they cannot be separated, so that the two of them become part of one another. Thus a husband must fully surrender himself to one wife. Third, one is commanded to unite in sexual union, to become one flesh. ${ }^{9}$

\section{Means of Generating Descendants}

God places the sex organs in the human body of course has a specific meaning. Many people think sexual activity is a reprehensible act. But many verses in the book are offensive about sexuality.

For a moment after God created Adam and Eve, God said: "Be fruitful and become many; fill the earth...." (Gen. 1:28), this is the main purpose of God giving sex. Through sexual intercourse in marriage that aims to produce offspring, God enables man to carry out and reflect His image by participating in creation or procreative. Thus marrying without any intention of producing offspring does not fulfill God's purpose. ${ }^{10}$

Children are a basic part of the goal of sexual relations in marriage, even if they are not the only goal. This does not mean that every sexual relationship in marriage must produce offspring but the desire to produce offspring should be a basic part of sexual relations in marriage.. ${ }^{11}$ Many people choose to enjoy their sex life in marriage without any desire to produce offspring. Various

\footnotetext{
${ }^{8}$ M.D. Wheat \& Gaye Wheat, Blissful Enjoyment (Jakarta: Barat Binapura Aksara, 1970), 85-97. Wheat and Gaye discussed four phases in sexual intercourse to reach the peak of one flesh, namely: stimulation or foreplay, increased excitation or plateau, orgasm which means excitation (overflow, joy, satisfaction), and relaxation..

${ }^{9}$ Ibid., 13-14.

10 The statement "failing to fulfill God's purpose" does not mean that any marriage that is unable to produce offspring is a failure. But it highlights the trend of "contract marriages" that occur among celebrities who are carried out with a single agreement not to produce offspring, because it is considered a binding. This act failed to fulfill God's purpose, because sex was considered only a means of satisfying lust.

${ }^{11}$ Samuelle Bacchiocci, The Marriage Covenant (Michigan: Bible Perspective, 1991), 76.
} 
kinds of contraceptives are used in sexual relations to avoid offspring, because children are considered a burden in marriage. People who think like this think sex is just self-gratification, not a gift from God that enables humans to produce offspring, is responsible for educating and guiding.

Of course not all couples are able to produce offspring, which may be caused by disease or disorder. The presence of children is a special gift to be grateful for (Deut. 713-14), the Psalmist also views as a reward (Ps. 127: 3-5). Apart from that, producing offspring is a joy to have been involved in the procreative creative activity where the angels rejoice with joy (Job 38: 7).

\section{Intimate Communication}

Through sexual relations in marriage will enable one another to know more closely which cannot be experienced in any other way. Couples who engage in sexual activity, not only reveal the entire covering of the body bound together but also bonded inwardly. That is why the Bible describes in the term "knowing" the same word the Hebrew book uses to know God. "And Adam knew his wife and she conceived," (Gen. 4: 1).

Of course before Adam had known Eve before, just as before two people were united in holy marriage, they had known each other first but through sexual intercourse they would "know" more intimately. This recognition is something unique that only every couple has. A husband knows his wife not the same as he knows his child.

Knowing through sexual intercourse means removing all self-covering, both physical and mental, to symbolize nothing hidden between them. Introduction through sexual intercourse is a process, starting from acquaintance, dating, engagement, marriage to sexual relations which is the culmination of the introduction of both partners. "Through sexual relations if there is something that is still hidden in the lives of both partners, it will be brought to the surface and presented to one another in a very intimate expression." 12

\section{Enjoyer}

Many people consider sexual intercourse in marriage to be a reprehensible act, and it only serves as a means of procreation. Indeed, Allah also intends to give sex in the marriage to give pleasure as a blessing other than to give offspring and to produce offspring. ${ }^{13}$

God Himself created sex so that husband and wife can enjoy it and develop a happy family. This is God's perfect plan for marriage, which can be entered at any time. The advice given by a

\footnotetext{
${ }^{12}$ Brian Craig, Beginnings A Pre-Marital Counselling Resource For Pastor (Manila, Philipines: Souhteast Adventist Division, 2002), 127.

${ }^{13}$ Samuele Bacchiocchi, The Marriage Covenant, 74.
} 
father to his son is: "Blessed be your well, rejoice with the wife of your youth: a sweet deer a beautiful deer; let her breasts satisfy thee at all times; and be thou ravished always with her love "(Prov. 5: 18,19).

We may be surprised that the Bible speaks openly and clearly about sex in marriage. Almost every book in the Bible says something about sex, and the hymn clearly explains the love relationship in a marriage (cf. 4: 10-12; 7: 10-12).

God's plan to have sex as a pleasure never changes, and we realize this especially in the creation of how miraculous and terrible our creation is (Ps. 139: 14). When we find many parts of our body that evoke strong and pleasant physical sensations that can be enjoyed by husband and wife, we can be sure that God makes us fully satisfied in marriage.

If we read the first three chapters of the book of Genesis, where it is written that God created man and woman, we find that "And God saw that it was good." In fact, sexual intercourse is so emphasized in the Bible that we begin to see that sexual intercourse is not only a pleasant and continuous experience between husband and wife, but is also intended to show us something more miraculous about God and his relationship with us (Eph 5: 31-32). So true sexual fellowship and done with the basis of love and mutual satisfaction is God's way of showing us great spiritual truth.. ${ }^{14}$

\section{Sanctity of Sex in Marriage}

Sex in marriage is something beautiful and intimate, which a husband and wife can do together especially in the freedom of love and that is sacred. ${ }^{15}$ Indeed, Allah planned them for the relationship. On the other hand, sex as a gift from Allah has caused man to fall into sin. After the fall of man into unholy sexual relations is frequent. Inauthentic behavior in defending God's good creation has failed. Sex is functioned against God's will.

Sex is something holy when used in marriage. Hebrews 13:14: "All of you are self-righteous and have full respect for your marriage, and do not tumble your bed, for God will judge prostitutes and adulterers." The word 'bed' in Heb. 13: 4, in Greek is koite ${ }^{16}$ which means "intercourse by inserting male sperm." Koite comes from the word keimai which means "lying down" and is the

\footnotetext{
${ }^{14}$ M.D. Wheat \& Gaye Wheat, Blessing Enjoyment, 11-17.

${ }^{15}$ Tim LaHaye, Liku-liku Pernikahan (Yogyakarta: Andi, 1990), 1.

${ }^{16}$ Black Alan, dkk., The Greek New Testament (German: United Bile Societies, 1983), 776.
} 
same as koimao which means "causing sleep." Based on the meaning of the word, then Ibr. 13: 4 can be translated, "sexual intercourse in marriage should be respected and not defiled. ${ }^{17}$

\section{Contraception in Marriage}

There is a debate whether contraceptives are permitted in marriage. For certain circles, there are those who think that contraception is wrong even if it is used only in marriage. ${ }^{18}$

Discussing whether contraception is something moral or not must see the purpose of marriage itself. Whether it is moral or not in using contraceptives is not seen from the type of device used but the reason for using it. If contraceptives are used outside of marriage and even in marriage but for selfinterest, it is against God's will in marriage. But if that tool is used for good reasons such as because of health, the kindness of the spouse and the integrity of the family which strengthens the marriage bond is something noble. Contraceptives can prevent the life of a Christian family couple from physical, emotional, mental and economic problems.

If sin does not enter this world, then contraceptives are not needed. Husbands will not struggle to earn a living, so women will not experience pain during pregnancy (Gen. 3: 16,19). The world is completely infected with the disease of sin, both the environment and the human mindset are deteriorating, the economic situation is weakening, the population density is not matched by means of job vacancies, education. So it is not a problem to use contraceptives because God requires humans to be responsible parents by educating them in God's teachings (Eph. 6: 4). The way to fulfill God's demands as parents is to build a family that is full of planning.

\section{Sex in a Sinful World}

Maintaining sexual holiness in the life of a Christian partner means living it according to God's plan. Various challenges that arise as the world develops. Sex abuse has developed such as mansturbation, adultery adultry and fornication, homosexual practice and others.

Sex is only part of a legal marriage if it is done in a marital relationship. The Bible strongly condemns the practice of sex outside of marriage, whether it's Fornication or Adutery, (Ex. 20: 5; Heb. 13: 4; I Cor. 6:18). The occurrence of sexual relations outside of marriage is due to low

\footnotetext{
${ }^{17}$ Barclay M. Newman Jr., Greek-Indonesian Dictionary for the New Testament (Jakarta: Gunung Mulia, 1994), 94.

${ }^{18}$ Samuelle Bacchiocchi, The Mariage Covenant, 79 says that the Roman Catholic Church thinks the use of contraception is wrong. December 1930, Pope Pus XI reaffirmed the Catholic church's stance on contraceptives through the encyclical Casti Cannubi. However, Pope Pius VI in his encyclical Humanae Vitae, July 29, 1968 emphasized that sexual relations are moral even if they are not intended to produce offspring. Humanae Canubi's letter distinguishes between natural and unnatural contraceptives. The natural is allowed while the unnatural is not allowed.
} 
understanding and weak commitment as a household basis. Some basic guidelines that will help couples in carrying out a sexual life in the household are: (1) The basis of sexual relations in a household is mutual relationship and honesty (I Cor. 7: 4-5). (2) Husband and wife need to communicate verbally their feelings and sexual urges. There is no play between partners in sexual relations. Everything must be open, nothing to cover. (3) Sexual relationships must be based on a strong commitment in order to build confidence in each other. Both partners must be active in the relationship with no one in the audience. ${ }^{19}$

Genesis 39: 8-9 tells the story of Joseph being invited to have sex with Potiphar's wife. Yusuf is estimated to be 19-21 years old, a young man but he has good principles about sex. Because sex is holy in God's eyes, thus: (1) Sex is a gift from God. Yusuf knows this, even if he has the opportunity (and possibly the desire). The Greeks had a dualism where the body was evil and the spirit was good. And many followers of God in the early days did not have the correct concept of sex. Sex seems like something taboo, disgusting, and doesn't need to be discussed. In fact, the Bible tells a lot about sex - true sex, sexual pleasure, and even sexual abuse (homosexuality, etc.). Research in the United States states that most youths have sex in their 15s. In their 11's, they have seen pornography. This means it can happen in any country. (2) sex is powerful, therefore must be controlled. David, Solomon, and even many world figures who fell because of sex. Anyone can fall, even a servant of God or an elder in a church! Sex is something that is powerful, which must be guarded carefully and seriously, because it can destroy human life. God is a holy God, and sex is only beautiful in marriage. Keep your life holy. People who truly love God want to keep their lives holy and so that they are more beautiful in His presence. Do not commit adultery, including enjoying pornography which is disgusting in God's eyes! ${ }^{20}$

Jesus allowed the woman to go and said, "I will not punish you either. Go away and sin no more from now on" (John 8:11). The text has the following meanings: (1) The truth that a person must know is that he is not alone. The woman who is involved in the sin of adultery is not alone, because the man who is with her is guilty. Sexual sin was also experienced by several well-known prophets in the Bible, such as David. From then on, everyone has struggled with sexual sin. From Bible times to your day, all struggled to escape. In Romans 3:23: "For all have sinned and fall short of the glory of God." This is why no one dared to throw stones at the woman, because all people have sinned even though their sins are different. (2) The truth of judgment comes from God, not from men. The religious leaders of the Bible are very happy to curse this woman and try to use her

\footnotetext{
${ }^{19}$ Jack O. Balswick \& Judith K. Balswick, The Family, 231-234.

${ }^{20}$ Victor Liu, "Seks according the bible", https://www.ebcmelbourne.org/sermons/seks-according-the bible/
} 
against Jesus and to use the Law. Satan works in the same way today. He uses punishment to create guilt, so that you feel ashamed and feel unworthy. In John 3:17, "God did not send his Son into the world to judge the world, but to save it by him." (3) The truth that God will continue to forgive you. Asking for forgiveness of sins seems like a simple statement but who among you has asked for forgiveness. In Matthew 18:22, Jesus said that we are to forgive one another seventy times seven. ${ }^{21}$

Sex Education as a Foundation of Christian Faith against the Doctrine of Holiness

Sexual activity outside premarital is a sin and schools are obliged to provide sex education to their students. In Leviticus 19: 2 it reads, "Speak to all the congregation of Israel and say to them, Be ye holy, for I, the Lord your God, are holy". The word "holy" in the original language (qadosh) means "to separate", separate; not pure white without blemish. The root word "qadosh" is truncated, to sanctify something is to separate. So the person who worships a holy God, who really understands that God is a holy God, that person sees his God as a very separate God, far beyond us, a God who is not us, a God who is far different from us. When we say that God has holy love, it means that His love is far beyond any kind of love that we can know. When we say that God has holy wisdom, it means that His wisdom is beyond all the wisdom we can know. In essence, saying that our God is holy means that we realize God is immeasurable, immeasurable.

Aspects of sanctification or sanctification (SAnctifICAtion) as a prerequisite for safety. Reformed theology that stems from the teaching tradition of Augustine and the reformers Martin Luther and John Calvin put a strong emphasis on salvation which is a gift of God alone (SoLA GRAtIA / GRAce Alone). The sanctification that leads to the spiritual growth (spiritual formAtion) of the believer is also not the result of human effort and work but is an act of God's grace. As with other aspects of salvation, in sanctification man does not have any merit that he contributes. Sanctification takes place in the human subconscious by the act of the Holy Spirit on $\operatorname{him}^{22}$

Thus sex education can be reconciled with the doctrine of holiness as the foundation of the Christian faith as follows: First, there is a need to develop holiness education in schools, seminars and in the church in order to clarify the position of sexual sin committed outside of marriage. Calvin sees sanctification as a real change in our lives to God, which is an act of killing the desires of the flesh and of old men, and living under the guidance of the Spirit. Sanctification is

21 Naomii Simbolon, "Having Sex Before Marriage? Is There Still God's Grace for Me? "Https://www.awaban.com/read/article/id/2019/02/22/80/190221165555/

22 Marde Christian Stenly Mawikere, (2016) "Reformed Theological Views of the Doctrine of Sanctification and its Present-day relevance", Jaffray Journal, 14 (2), 199-228. 
equal to knowledge of God. Knowledge that is not only the nature of the presence, but also the predestination, in which God chooses each person as an individual according to His own will. ${ }^{23}$ Holiness means the change of human attitudes or actions from living according to the flesh and the old man to the leadership of the Holy Spirit. In the sanctification is the real action of God who chooses and sanctifies the believer according to His own will. Or in other words, Calvin talks about new birth (regeration).

In the Institutes it states, "object the object of regeneration is to bring the life of believers into concord and harmony with the righteousness of God, and so confirm the adoption by which they have been received as sons... the image of God is restored in us." 24

Second, God-centered holiness becomes dependent only on God and not on humans. This holiness has two stages as follows: The first holiness (salvation) a person experiences when he believes and accepts Jesus Christ as his Savior and Lord. In Jesus Christ, a holy person is seen by God the Father as a special person: the righteous, the children of God. The first holiness should be followed by the second holiness, namely: offering one's self to Him. An offering means that a person separates what he has for Allah. The offering meant that in his mind something special was set apart for Allah. There are many things that he can offer to Allah: money, possessions, etc., but what he mainly offers to God is his own life.. ${ }^{25}$

Third, the holiness exemplified by Jesus becomes an exemplary figure that everyone can imitate so that everyone has a calling to live. In Deuteronomy 18:13 it says that "therefore ye shall be perfect, as your Father which is in heaven is perfect." for I, the Lord your God, am holy (Leviticus 19: 2) and in the Book of Deuteronomy, "You shall live blameless before the Lord ..." (Deut. 18:13). Thus that everyone is called to be a saint. This call to live a holy life is very important, because in fact, it is only by living in holiness. ${ }^{26}$

Psalm 50:21 God says: "This is what thou shalt do, but I am silent; you think that I am equal to you. I will punish you and bring this matter before you. " The entire section of Psalm 50 states "I am different from you and you do not realize it, that is one of the problems you have." God's rebuke to the Israelites was not only about adultery, stealing, etc. but "do not think I am the

\footnotetext{
${ }^{23}$ J. Graham Miller, Calvin's Wisdom (Edinburgh: The Banner of Truth Trust, 1992), 324.

24 John Calvin, Institutes of the Christian Religion. Vol. 3 (Grand Rapids: WM. B. Eerdmans Publishing Company, 1997), 2.

${ }^{25}$ Heru Tri Budiyanto, "Holiness and the Prsembahan of Life", https://kirbatbaru.org/renungan-hariini/popup/text/print/1265.

${ }^{26}$ Lihat Joseph Ratzinger, Pope Benedict XVI, Jesus of Nazareth, (Double Day, New York, 2007), 74, "The Beatitudes present a sort of veiled interior biography of Jesus, a kind of a portrait of His figure. He who has no place to lay His head (Mt 8:20) is truly poor, He who can say...I am meek and lowly in heart (Mt 11:28-29) is truly meek; He is the one who is pure of heart and so unceasingly beholds God. He is the peacemaker, He is the one who (obediently) suffers for God's sake.
} 
same as you!". So the meaning of holiness for a human being, simply means belonging to God completely; There is nothing in our lives that is not owned by God, there is nothing in our life that is not under God's judgment, there is not a single part of our heart that is not attached to God's heart. $^{27}$

\section{CONCLUSION}

The Bible's view of sex education is God's work on humans since creation. Equipped with the sexual organs, sensual feelings are given to man as a blessing to be enjoyed in marriage. On the other hand, the mandate is to be active in creation (procreative) by procreating through sexual intercourse. A man leaves his mother and father united with his wife as one flesh, both naked but not ashamed, to enter into an intimate relationship that can only be experienced through sexual intercourse. These are the things God aims for sexual relations in marriage.

Sex is something sacred as God instituted the first marriage in Eden. Therefore the Bible clearly condemns the practice of unholy relationships in marriage. On the other hand, Christian family couples are invited to carry out sexual relations in the household according to the divine will.

Sex education can be related to the doctrine of holiness as the foundation of Christian faith as follows: First, the need to develop holiness education in schools, seminars and in churches in order to clarify the position of sexual sinfulness that is committed outside of marriage. Second, God-centered holiness becomes dependent only on God and not on humans. Third, the holiness modeled by Jesus becomes a figure that everyone can imitate so that everyone has a calling to live.

\section{References}

"The Holiness of Allah and Our Holiness" :, https://griikg.org/kekudusan-allah-dan-kekudusankita/.

Alan, Black. et al. The Greek New Testament. German: United Bile Societies, 1983.

Aziz, Safrudin. (2014), "Sex Education for Children with Special Needs", Journal of Education, II (2), 203.

Bacchiocci, Samuelle. The Marriage Covenant. Michigan: Bible Perspective, 1991.

Balswick, Jack O. \& Balswick, Judith K. The Family. Grand Rapids, Michigan: Baker Book, 1989. Budiyanto, Heru Tri. "Holiness and the Prsembahan of Life", https://kirbatbaru.org/renungan-hariini/popup/text/print/1265.

Calvin, John. Institutes of the Christian Religion. Vol. 3. Grand Rapids: WM. B. Eerdmans Publishing Company, 1997.

27، Kekudusan Allahn dan Kekudusan Kita ”, https://griikg.org/kekudusan-allah-dan-kekudusan-kita/. 
Craig, Brian. Beginnings A Pre-Marital Counseling Resource For Pastors. Manila, Philipines: Souhteast Adventist Division, 2002.

Koten, Angelikus N., Margiani, Kristin, Bunga, Beatriks N. \& Mau, Timoteus. (2019), "Parents' Perpesi on Sex Education for Children aged 4-5 Years in Manleten Village, Tasifeto Timur District, Belu Regency." Journal of Humanizing Human Education, XVIII (2), 79.

LaHaye, Tim. The Twists of Marriage. Yogyakarta: Andi, 1990.

Liu, Victor. "Sex according to the Bible", https://www.ebcmelbourne.org/sermons/seks-menurutalkitab/

Mawikere, Marde Christian Stenly. (2016) "The Reformed Theological View of the Doctrine of Sanctification and its Present-day relevance”, Jaffray Journal, 14 (2), 199-228.

Miller, J. Graham. Calvin's Wisdom. Edinburgh: The Banner of Truth Trust, 1992.

Newman, Barclay M. Greek-Indonesian Dictionary of the New Testament. Jakarta: Gunung Mulia, 1994.

Nuryadi. (2016), "Reproductive (Sex) Education in Adolescents," Journal of Religion and Society Studies, 12 (1), 82.

Ratzinger, Joseph Ratzinger. Pope Benedict XVI, Jesus of Nazareth. Double Day, New York, 2007. Rosela, Ria Rosela and Lukitaningsih, Retno. (2014), "A Survey on the Understanding of Sex Education for Class X Students at SMK Dr. Soetomo Surabaya ". Journal of BK UNESA, 04 (03), 1-12.

Simbolon, Naomii. "Having Sex Before Marriage? Is There Still God's Grace for Me?

"Https://www.awaban.com/read/article/id/2019/02/22/80/190221165555/melakukan_hkon_seks_se belum_nikahmasihkah_ada_anugerah_tuhan_untukku.

Wheat, M.D. \& Wheat, Gaye. Enjoyment Full of Blessings. Jakarta: West Binapura Script. the "Insert Citation" button to add citations to this document. 